\title{
Research into influence of drilling-and-blasting operations on the stability of the Kusmuryn open-pit sides in the Republic of Kazakhstan
}

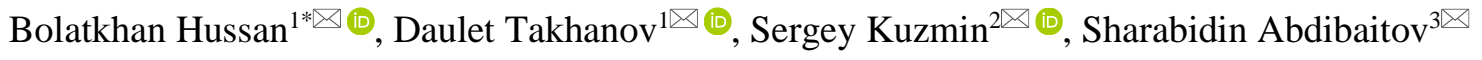 \\ ${ }^{1}$ Karaganda Technical University, Karaganda, 10018, Kazakhstan \\ ${ }^{2}$ Rudny Industrial Institute, Rudny, 10009, Kazakhstan \\ ${ }^{3}$ Kyrgyz State University of Geology, Mining and Natural Resources Development named after Academician Usengazy Asanaliev, Bishkek, \\ 720001, Kyrgyzstan \\ *Corresponding author: e-mail hbolat@mail.ru, tel.+87765257720
}

\begin{abstract}
Purpose. Research into influence of drilling-and-blasting operations on the nature of deformation in near-side masses of the design open-pit contours and assessing the seismic impact of blasting operations, which are the basis for development of recommendations on the rational parameters of drilling-and-blasting operations.

Methods. The influence of drilling-and-blasting operations at the limiting contour of the Kusmuryn field is studied using the analysis of the mining-and-geological conditions and tectonics of the rocks constituing the field, in-situ surveying the state of the open-pit sides, analysis of the physical and mechanical properties of the host rocks, analytical studies and instrumental measurements of the blasting effect.

Findings. Based on the analytical methods, the calculation and analysis of the seismic stability of the rocks at the field have been performed. By means of instrumental measurement of the blasting effect in open pit, data have been obtained on the seismic impact of blasting operations on the near-side masses. According to the results of these works, rational parameters of drilling-and-blasting operations at the limiting contour of the open pit have been determined. In addition, the main provisions for the organization of drilling-and-blasting operations at the limiting contour of the open pit have been developed.

Originality. In this work, for the first time, a joint research method is applied, which includes an analytical calculation of the shock wave seismic impact on a rock mass, based on the results of which the dependency graphs have been obtained of the seismicity coefficient on the rock hardness coefficient at the Kusmuryn field according to the Protodyakonov scale for various explosives, as well as using the method of instrumental measurements, which serves to determine the seismic impact of an explosion on a rock mass. This makes it possible to substantiate the technology of conducting the drilling-and-blasting operations at the contour, providing a long-term stable position of the permanent side of the open pit.

Practical implications. The results of the work will be used to calculate the safe parameters of conducting the blasting operations when placing the side in the final position at the Kusmuryn field. This research method can be applied at any mining enterprise conducting open-cut mining of minerals.
\end{abstract}

Keywords: blasting, stability, side, open pit, seismic impact, blast-hole

\section{Introduction}

Nowadays, mining enterprises are at the stage of the need to make a number of managerial, technical, and social decisions aimed at reducing the cost of finished products. In the current market of copper raw materials and direct competition of such enterprises, only a decrease in the cost of manufactured products will ensure the retention of consumers, which means stable development and preservation of jobs [1]-[3].

When mining the flat-dipping ore bodies by the open-cut method, drilling-and-blasting operations occupy a special position. They, as the initial process of ore mining, determine the efficiency of all subsequent processes: loading, transportation, crushing and processing of mineral raw materials [4][6]. The main tasks during drilling-and-blasting operations are: increasing their technical and economic efficiency; ensuring the required quantity and quality of the blasted rock mass; reducing the risk of large-scale blasting operations and their negative impact on the environment [7].

The drilling-and-blasting complex is one of the most cost-intensive sectors (sectors, the costs of which currently require reduction) of a mining enterprise. As it is known, 
when conducting the mining operations in open pits, ensuring the stability of the working sides depends on many factors, including the mining-and-geological conditions and the tectonics of the field, as well as the impact of drilling-andblasting operations on the near-side mass. This is especially important when mining is approaching the design limiting contour of the open pit, where the requirements for technological blasting change [8].

One of the main requirements for the technology of breaking at the limiting contour of the open pit is to ensure the maximum degree of preservation of the formed rock benches - the slope and the berm. This is conditioned by the need to maintain a safe state of the benches for a sufficiently long time of the open pit existence [9], [10]. The main way to fulfil this requirement is obvious: it is necessary to reduce the intensity of technogenic impact on the surrounding rock mass to the minimum acceptable level, which would ensure, on the one hand, a sufficient degree of preservation of the marginal mass, on the other hand, sufficient produce-ability of drilling-and-blasting operations. To ensure the pit side stability, technologies of the contour blasting operations have been developed, which make it possible to suppress the effect of an explosion on rocks [11]-[15], as well as a number of mining technologies that make it possible to reduce the impact of technological equipment on the open pit permanent side [16], [17].

The main parameters of the Kusmuryn open pit: length (from north to south) - $450 \mathrm{~m}$; width (from west to east) $400 \mathrm{~m}$; open pit depth up to the mark 720-110 m. The vehicle route is circumferential one along all sides of the open pit.

Previously, there were 3 main deformation zones in open pit: northern, southern, western, where the deformation of the slopes was observed practically to the entire height of the side. Haulage berms within these zones had deformations. Rows of local deformations and areas with overhanging rock blocks were noted along the open-pit sides.

In 2018, deformation processes were observed during mining operations along the northern side at marks of $820 \mathrm{~m}$ and $830 \mathrm{~m}$. Deformations were manifested in the form of fractures, as well as the fractures across the side with subsidence along the rupture fracture, namely:

- at the horizon of $830 \mathrm{~m}$, the deformation length was $67 \mathrm{~m}$; width of opening $-25 \mathrm{~cm}$, depth of visible opening $-2.46 \mathrm{~m}$;

- at the horizon of $820 \mathrm{~m}$ (north-eastern area), the deformation length was $28 \mathrm{~m}$; width of opening $-12 \mathrm{~cm}$; depth of visible opening $-90 \mathrm{~cm}$;

- at the horizon of $820 \mathrm{~m}$ (northern area), the deformation length was $53 \mathrm{~m}$; width of opening $-92 \mathrm{~cm}$; depth of visible opening - $3.77 \mathrm{~m}$;

- at the horizon of $820 \mathrm{~m}$ (in the berm centre), width of opening $-80 \mathrm{~cm}$; subsidence along the rupture fracture $-226 \mathrm{~cm}$.

Currently, at the Kusmuryn open pit, mining operations are being conducted along the north-eastern and southeastern sides (Fig. 1).

When conducting the blasting operations, the stability of the open-pit sides is influenced by the seismic impact of the explosion. A substantiated assessment of the seismic hazard degree allows, based on the competent engineering, to control the volume of blasting operations, especially in the conditions of the open-pit limiting contour, when it is necessary to reduce the intensity of destruction to a minimum in the open-pit side, which will be left for a long time.

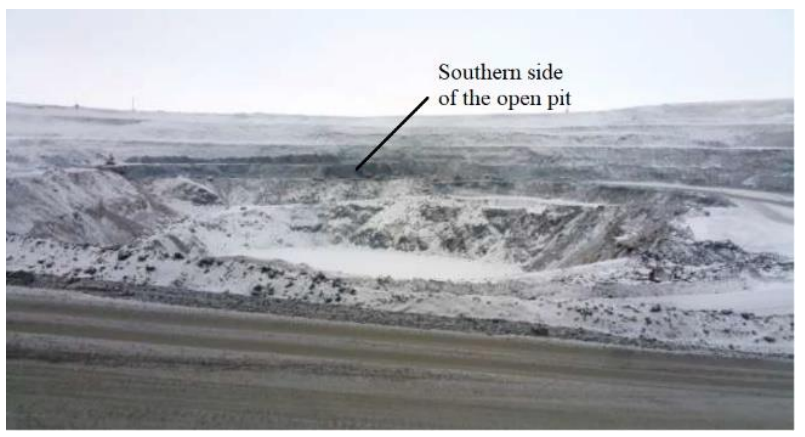

Figure 1. State of the sides in the area of mining operations (southern side) (photo - February, 2020)

\section{Methods}

The seismic impact intensity of the explosion is determined by the parameters of the arising stress wave. The knowledge about this wave formation makes possible to solve a number of practical problems and, in particular, to assess the value of the seismicity coefficient of the mass, that is its ability to transmit wave loads [18].

The seismicity coefficient of a rock mass characterizes the degree of its elastic response to external dynamic influence and is a parameter that determines the elastic seismic wave intensity with distance from the site of blasting operations.

To determine the patterns for the propagation of an elastic wave over a mass, a simplified model is used. Let us represent a source of an elastic wave in the form of a sphere bounded by the area of ultimate destructions and having an initial reserve of elastic energy:

$$
E_{e l}=e_{s} \cdot 4 \cdot \pi \cdot R_{p}^{2},
$$

where:

$e_{s}$ - energy flux density at the boundary of the area at the moment of maximum expansion of the chambered cavity, $\mathrm{kg} / \mathrm{m}^{2}$;

$R_{d}$ - size of the area of ultimate destruction, $\mathrm{m}$.

On the other hand, the reserve of elastic (potential) energy can be represented in the form of kinetic energy:

$$
E_{k}=\frac{M_{e l} \cdot v_{c r}^{2}}{2 \cdot g},
$$

where:

$M_{e l}$ - the weight of the rock in the elastic area, $\mathrm{kg}$;

$v_{c r}$ - initial displacement velocity at the boundary of the elastic area, $\mathrm{m} / \mathrm{s}$.

With the subsequent propagation of the accumulated energy through the mass, the sequentially increasing rock volume (and, accordingly, the mass) is involved in movement. If to suppose that the process of elastic energy propagation occurs without significant losses (this assumption is substantiated by the condition that there is no the rock destruction beyond the elastic source), then proceeding from the energy conservation law of the entire system (mass is the source), the equality can be written as follows:

$$
\frac{M_{e l} \cdot v_{c r}^{2}}{2 \cdot g}=\frac{M \cdot v^{2}}{2 \cdot g},
$$

where:

$M$ - total weight of the rock involved in movement in the elastic area, $\mathrm{kg}$. 
If to neglect the smallness of the rock compaction value (assume $\gamma_{\text {rock }} \approx$ const) for the volumes of the corresponding areas, it can be written:

$V_{e l}=\frac{4}{3} \cdot \pi \cdot\left(R_{p}^{3}-R_{0}^{3}\right)$

$V=\frac{4}{3} \cdot \pi \cdot\left(R^{3}-R_{0}^{3}\right)$

where:

$R_{0}-$ charge radius, $\mathrm{m}$.

Taking this into account, the value of the mass displacement velocity at a distance $\mathrm{R}$ from the charge is determined $\left(R \geq R_{p}\right)$ :

$v=v_{c r} \cdot\left[\left(\frac{R_{p}}{R_{0}}\right)^{3}-1 /\left(\frac{R}{R_{0}}\right)^{3}-1\right]^{\frac{1}{2}}$.

Neglecting the unity smallness in comparison with the values $\left(\left(R_{p} / R_{0}\right)^{3}\right.$ and $\left(R / R_{0}\right)^{3}$, it can be written:

$v=v_{c r} \cdot\left(\frac{R_{p}}{R}\right)^{1.5}$.

After finding the values of $v_{c r}$ and $R_{d}$, the final form of the formula, corresponding to the form of the well-known formula of M.A. Sadovsky, can be obtained [19]:

$v=k_{c} \cdot\left(\frac{Q^{1 / 3}}{R}\right)^{1.5}$.

Equality in this formula characterizes the intensity of the seismic impact of a charge placed in the mass at a sufficiently large distance from the free surface.

In this case, the value of the seismicity coefficient of the mass $k_{s}$ is determined as follows:

$k_{c}=0.13 \cdot f^{0.395} \cdot\left[(1-\eta) \cdot U_{s p}\right]^{0.25}$,

where:

$f$-rock hardness coefficient according to the Protodyakonov scale;

$\eta$ - fraction of the initial energy remained in the detonation products at the moment of complete expansion of the chambered cavity, units [20], [21].

$\eta=\frac{\gamma_{0}-1}{k-1} \cdot \frac{373}{\gamma_{B B}}\left(\frac{\sigma_{\text {comp }}}{P_{0}}\right)^{\frac{k-1}{k}}$,

where:

$\sigma_{\text {comp }}$ - uniaxial compression strength of rocks, $\mathrm{kg} / \mathrm{m}^{2}$;

$k$ - the minimum value of the adiabatic exponent at a density of $\gamma_{\text {expl }}=373 \mathrm{~kg} / \mathrm{m}^{3}$, is taken equal to 1.4 ;

$\gamma_{\text {expl }}$ - volume weight of the explosive, $\mathrm{kg} / \mathrm{m}^{3}$ [22];

$\gamma_{o}$ - initial adiabatic exponent for the expansion of highdensity detonation products, units.

$\gamma_{0}=\sqrt{1+\frac{\gamma_{B B}^{1.2}}{1270}}$
$P_{0}-$ initial pressure of detonation products, $\mathrm{kg} / \mathrm{m}^{2}$, can be represented as follows:

$P_{0}=\left(\gamma_{0}-1\right) \cdot \gamma_{B B} \cdot U_{s p}$,

where:

$U_{s p}-$ specific energy of explosive, $\mathrm{kgm} / \mathrm{kg}$, is determined by the formula:

$U_{s p}=427 \cdot Q$,

where:

$Q$ - specific heat of explosion, $\mathrm{kcal} / \mathrm{kg}$ [23];

427 - mechanical equivalent of thermal energy, $\mathrm{kgm} / \mathrm{kcal}$.

In order to determine the degree of impact of blasting operations, in accordance with the adopted passport of drilling-and-blasting operations, experimental studies are organized. To determine the seismic impact of the explosion on the rock mass, the Ellis-3 seismic-acoustic system is used. This system is designed for shallow seismic surveys with various sources of seismic wave excitation: impulse, explosive, "dropweight", sledgehammer. The main sphere of application is conducting the engineering research in order to study the structure of the Earth to depths of $1.5 \mathrm{~km}$, depending on the used source of excitation of seismic vibrations [24]-[26].

The layout of the observation stations is shown in Figure 2. After each explosion, a survey of fractures is performed at organized observation stations. This makes it possible to assess the dynamics and the degree of gradual development of technogenic fracturing, as well as a decrease in the rock mass stability.

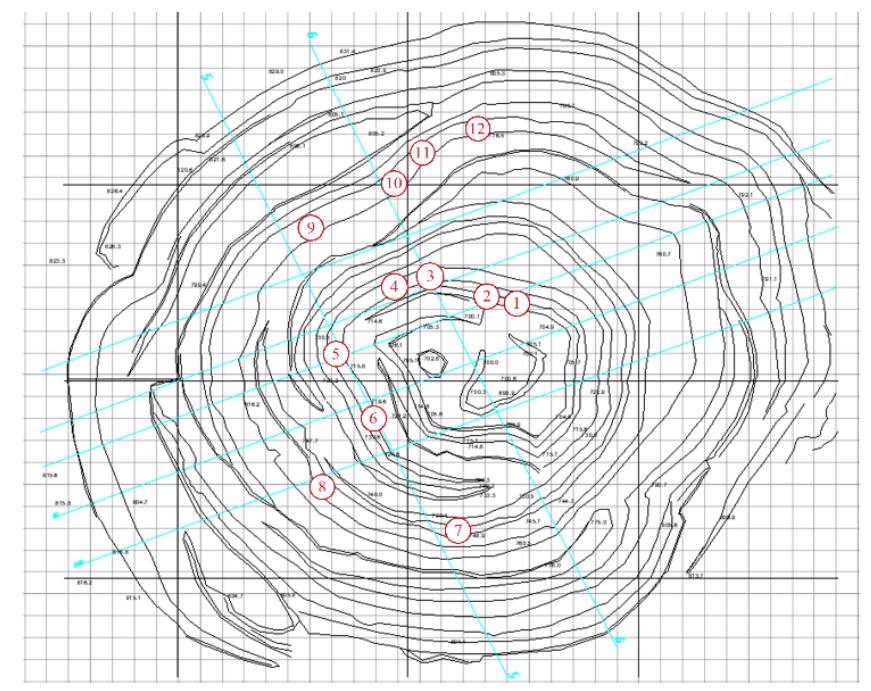

Figure 2. Layout of observation stations along the contour of the open-pit side

The propagation of the seismic wave of the explosion in the studied area is studied using the placed observation stations. There are 12 stations in total.

\section{Results}

Based on the calculation results, the dependency graphs (Fig. 3) of the seismicity coefficient on the coefficient of rock hardness of the Kusmuryn field have been obtained according to the Protodyakonov scale for explosives of the Petrogen D70 type at an explosive density $\gamma_{\text {espl }}=1050 \mathrm{~kg} / \mathrm{m}^{3}$ (curve 1) and $\gamma_{\text {espl }}=1250 \mathrm{~kg} / \mathrm{m}^{3}$ (curve 2). 


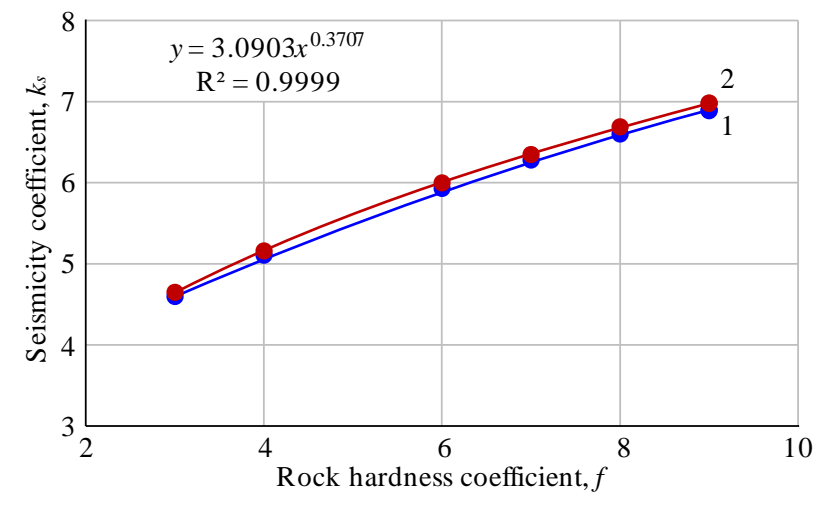

Figure 3. Dependency graph of the seismicity coefficient on the coefficient of rock hardness

It can be seen from the graph (Fig. 3) that a high correlation coefficient $\left(K_{\text {corr }}=1\right)$ indicates a stable relationship between the seismicity coefficient $k_{s}$ and the rock hardness coefficient $f$ as the main technological indicator.

As known, the key factor that significantly influences on the stability of rock benches is the systematic production of large-scale explosions in open pit. Regular dynamic loading of the rock mass can cause failure of local areas in the open-pit side if the value of the maximum recorded displacement velocity exceeds the permissible limit for this studied area of thr side [23]. In turn, the displacement velocity for different areas of the open-pit space can vary within a fairly wide range. This happens mainly because of the different reaction of the rock mass to the dynamic load caused by a large-scale explosion. As an estimate of the displacement velocity, the dependence of M.A. Sadovsky (Formula 8) is commonly used, which determines the relationship between the value of the soil displacement velocity $(v)$, the mass of the charge for blasting $(Q)$ and the distance $(r)$ at which this velocity value is fixed or planned to be found. The graph of a change in the mass displacement velocity (for andesites) is shown in Figure 4.

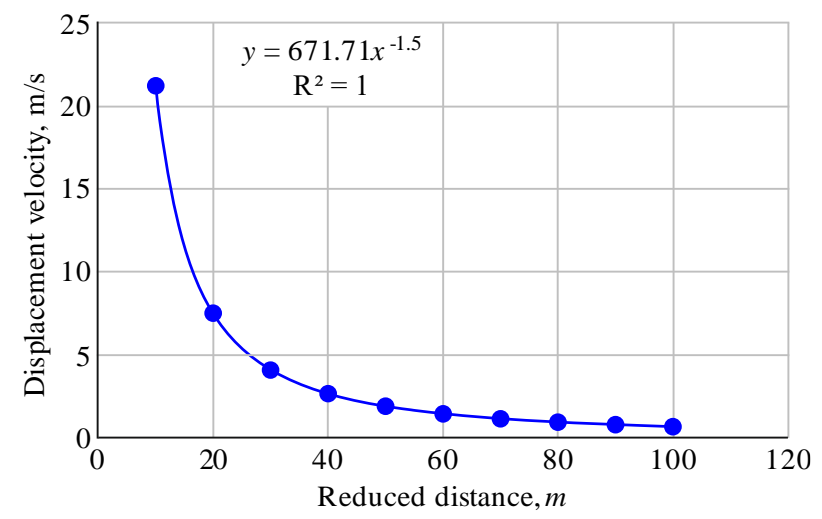

Figure 4. Graph of a change in the mass displacement velocity (for andesites)

Next, the initial displacement velocity $v_{c r}$ at the boundary of the elastic area is found. The value of $v_{c r}$ can be obtained from the equality:

$v_{c r}=\frac{2 \cdot \sigma_{c o m p} \cdot g}{\gamma_{n} \cdot c_{p}}$.
Substituting the data on the physical and mechanical properties of each rock of the field, which are given in the above section, the initial displacement velocity at the boundary of the elastic area can be found (Table 1).

Table 1. Results of calculating the initial displacement velocity at the boundary of the elastic area

\begin{tabular}{lcccc}
\hline \multicolumn{1}{c}{ Rock type } & $\begin{array}{c}\text { Uniaxial } \\
\text { compression } \\
\text { strength, } \\
\sigma_{\text {comp }}, \mathrm{MPa}\end{array}$ & $\begin{array}{c}\text { Rock } \\
\text { density, } \\
\gamma \cdot 10^{-3}, \\
\mathrm{kgs} / \mathrm{m}^{3}\end{array}$ & $\begin{array}{c}\text { P-wave } \\
\text { velocity, } \\
V_{p}, \mathrm{~m} / \mathrm{s}\end{array}$ & $\begin{array}{c}\text { Initial } \\
\text { displacement } \\
\text { velocity, } \\
v_{c r}, \mathrm{~m} / \mathrm{s}\end{array}$ \\
\hline Andesites & 87 & 2.85 & 6074 & 10.0 \\
\hline Dacitic tuffs & 77 & 2.74 & 5694 & 9.8 \\
\hline $\begin{array}{l}\text { Stockwork } \\
\text { mineralization }\end{array}$ & 72 & 3.74 & 5215 & 7.3 \\
\hline $\begin{array}{l}\text { Rhyolitic tuffs } \\
\text { (sub-ore zone) }\end{array}$ & 41 & 2.84 & 4653 & 6.2 \\
\hline $\begin{array}{l}\text { Rhyolitic tuffs } \\
\text { (sub-ore zone) }\end{array}$ & 27 & 2.73 & 3463 & 5.7 \\
\hline $\begin{array}{l}\text { Rhyolitic tuffs } \\
\text { (sub-ore zone) }\end{array}$ & 63 & 2.80 & 5308 & 8.5 \\
\hline $\begin{array}{l}\text { Rhyolitic tuffs } \\
\text { (sub-ore zone) }\end{array}$ & 86 & 2.77 & 5705 & 10.8 \\
\hline
\end{tabular}

As can be seen from the results of calculating the initial displacement velocity at the elastic area boundary (Table 1), the highest critical displacement velocity is in andesites and tuffs, the uniaxial compression strength $\sigma_{\text {comp }}$ of which is up to $90 \mathrm{MPa}$. The lowest critical displacement velocity is in rhyolitic tuffs with the uniaxial compression strength of $27 \mathrm{MPa}$. The calculation results show the dependence of the initial displacement velocity on the uniaxial compression strength of rocks.

According to the results of numerical modeling of seismic wave propagation after the explosion in the studied mass area, the critical values of the vibration velocities have not been revealed. However, as a result of rereflections and mutual interference of stress waves, local areas of dynamic loading can be formed, which, in combination with acting static stresses, can have an adverse influence on the rock mass state. This is manifested in a decrease in the strength characteristics of individual mass areas due to the opening of old and the formation of new fractures. The specified influence mainly affects the areas in the vicinity of contacts of various lithological differences and geological disturbances.

Thus, as a result of the analysis of seismic data and comparison of fracture surveys, it has been determined that the degree of influence of blasting the explosive charges on the mass is moderate. The revealed deformations are confined to the zones of geological disturbances.

\section{Discussion}

When conducting the research, the smallest destruction of the open-pit side has been revealed, when the distance between the holes for preliminary presplitting is $2 \mathrm{~m}$ and the charge length is not more than $2 / 3$ of the hole length. In this case, various schemes of wiring-up for blasting the charges are used. The use of diagonal short-delay blasting schemes reduces the width of the residual deformation zone in the upper area of the bench by 1.3-2 times in comparison with row-by-row blasting.

The use of inclined charges for breaking the rocks with an angle of inclination of $60-75^{\circ}$ to the horizon can sharply reduce the width of the disturbed zone; the slope surface remains disturbed to a depth of 10-12 charge diameters. Hole placement grid is $5 \times 5 \mathrm{~m}$. In large-block, weakly weathered rocks above the average hardness $(f>10)$ and in the absence 
of fractures falling towards the mined-out space, the breaking of the border belt with inclined charges is a sufficient measure to ensure long-term stability of the benches. The simultaneous use of inclined charges makes it possible to reduce the overdrilling value by 1.5-2 times, which reduces the destruction of the underlying layer.

The use of diagonal short-delay blasting schemes and inclined holes does not require special additional costs. These methods are also very effective when improving the quality of rock breaking and crushing and can be recommended as permanent methods for drilling-and-blasting operations.

The basic principles that should be observed when developing specific technological solutions are as follows (Fig. 5):

- with the purpose of ensuring the rock mass preservation in the volume of the future bench (in its limiting position), the boundary 1 of zone $A$ of the main large-scale breaking should not approach the design bench contour (in the absence of a contour gap) by the width of the protecting zone $L_{\text {prot }}=L_{1}+L_{2}$, which is determined from the condition of absent residual deformation beyond the design bench contour;

- after the contour gap formation, rock breaking within the protecting zone should be conducted in a sparing mode, for which the protecting zone is divided into two zones of breaking: zone $C$, within which it is permissible to use blastholes of the main diameter, and zone $B$, within which it is necessary to use blast-holes of a reduced diameter (for example, $105-150 \mathrm{~mm}$ ).

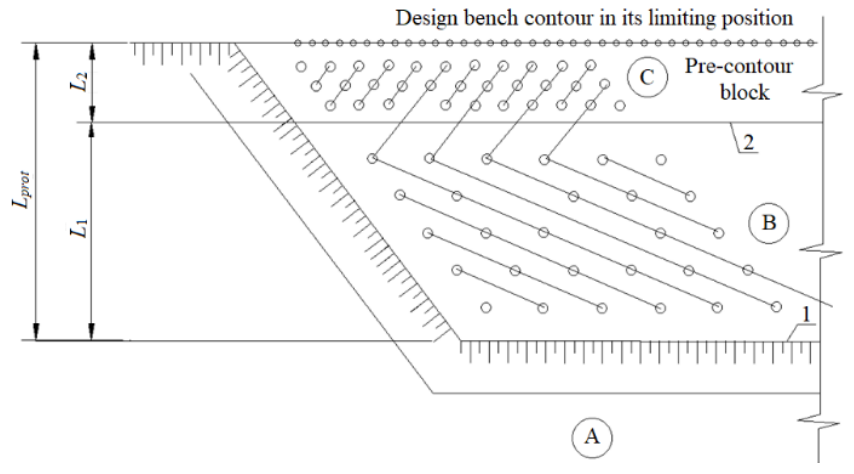

Figure 5. Basic wiring-up diagram: A-large-scale breaking zone; $B$-protecting zone with the use of holes of the main diameter; $C$-protecting zone with the use of holes of reduced diameter; 1 -protecting zone boundary; 2 -pre-contour block boundary; $L_{\text {prot }}-$ the width of the protecting zone; $L_{1}-$ the width of the protecting zone with the use of holes of the main diameter; $L_{2}-$ the width of the protecting zone with the use of holes of reduced diameter

In this case, breaking within the pre-contour block is performed in advance in relation to the main technological breaking. The initiation scheme (Fig. 5) is organized in such a way that the technological hole closest to the precontour block is blasted on the already formed area of the protecting layer, which is able to screen up to $60 \%$ of the dynamic impact energy of charges in the blast-holes with large diameter.

It is necessary to use Interit-20E as explosive, with the use of reverse initiation. In this case, the charge mass decreases by $20-30 \%$, for holes of the I and II rows, and for holes of the III row, the charge mass decreases by $10-20 \%$. Drilling is performed without overdrilling (Fig. 6).

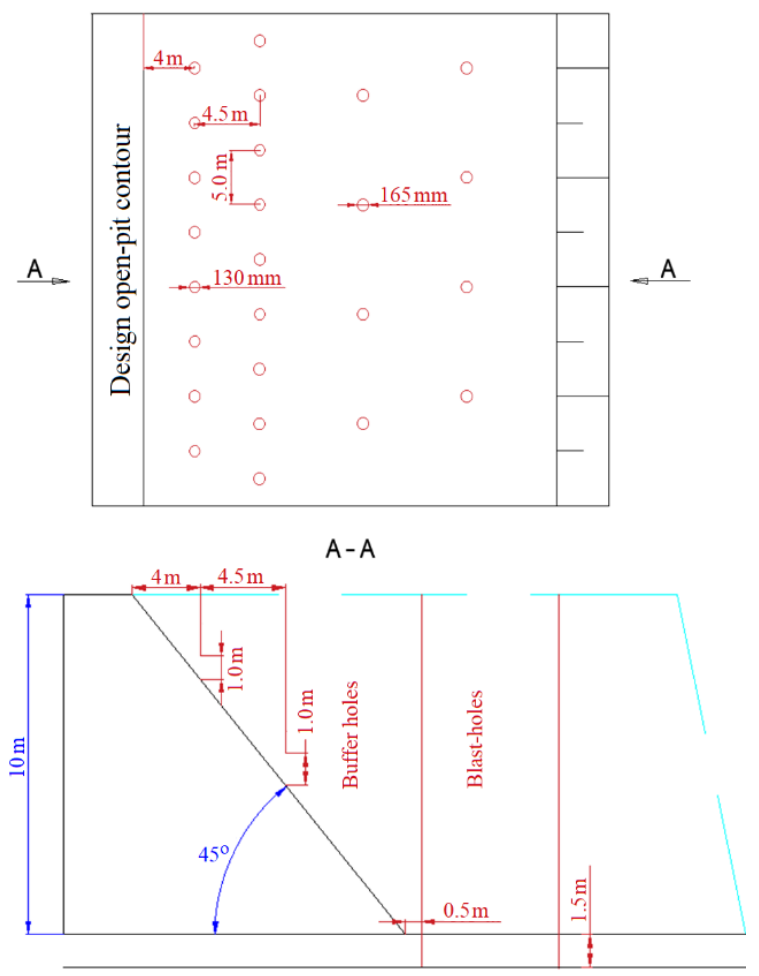

Figure 6. Layout of holes according to the method of drilling the vertical holes of small diameter

\section{Conclusions}

As a result of the research performed, the rock mass seismicity coefficients, as well as the lowest displacement velocity for the rocks of the Kusmuryn field have been determined. Seismic studies have been performed for determining the velocity of propagation of elastic waves arising in a rock mass as a result of an explosion. Based on the results of numerical modeling of the seismic wave propagation after explosion in the studied mass area, the critical values of the vibration velocities have not been revealed.

When drilling with a diameter of $165 \mathrm{~mm}$, it is recommended to reduce the distance between holes for preliminary presplitting to $2 \mathrm{~m}$ with a charge length of no more than $2 / 3$ of the hole length. The least influence on the open-pit side is exerted by the use of diagonal short-delay blasting schemes, which reduce the width of the residual deformation zone in the upper area of the bench by 1.3-2 times in comparison with row-by-row blasting.

After the formation of a contour gap, rock breaking within the protecting zone should be performed in a sparing mode, for which the protecting zone is divided into two zones of breaking, within which it is permissible to use blastholes of the main diameter, and a buffer zone, within which it is necessary to use blast-holes of reduced diameter. In this case, the charge mass in a buffer zone decreases by $20-30 \%$, for holes of the I and II rows, and for holes of the III row, the charge mass decreases by $10-20 \%$.

\section{Acknowledgements}

We would like to express our gratitude to all the editorial staff and reviewers for the high-quality work on our material. We are pleasantly surprised by the prompt and wellorganized feedback from the editorial staff. It is worth noting the clear and well-coordinated work of the team. We express 
our gratitude to Bakhtybaev Nurbol Bakhtybaevich and Takhanov Daulet Kuatovich for valuable advice when planning the research and recommendations on the design of this paper. The authors are also grateful to colleagues who helped the authors with the work on the manuscript.

\section{References}

[1] Dryzhenko, A., Moldabayev, S., Shustov, A., Adamchuk, A., \& Sarybayev, N. (2017). Open pit mining technology of steeply dipping mineral occurences by steeply inclined sublayers. International Multidisciplinary Scientific GeoConference Surveying Geology and Mining Ecology Management, 17(13), 599-606. https://doi.org/10.5593/sgem2017/13/s03.076

[2] Sobko, B., Drebenstedt, C., \& Lozhnikov, O. (2017). Selection of environmentally safe open-pit technology for mining water-bearing deposits. Mining of Mineral Deposits, 11(3), 70-75. https://doi.org/10.15407/mining11.03.070

[3] Symonenko, V.I., Haddad, J.S., Cherniaiev, O.V., Rastsvietaiev, V.O., \& Al-Rawashdeh, M.O. (2019). Substantiating systems of open-pit mining equipment in the context of specific cost. Journal of the Institution of Engineers (India): Series D, 100(2), 301-305. https://doi.org/10.1007/s40033-019-00185-2

[4] Kyrgizbayeva, G., Nurpeisov, M., \& Sarybayev, O. (2015). The monitoring of earth surface displacements during the sub-soil development. New Developments in Mining Engineering, 161-167. https://doi.org/10.1201/b19901-30

[5] Zhanakova, R., Pankratenko, A., Almenov, T., \& Bektur, B. (2020). Rational selection of the form of support for the formation of genetic composition of rocks in the conditions of the beskempir field. News of the National Academy of Sciences of the Republic of Kazakhstan, Series of Geology and Technical Sciences, (439), 106-113. https://doi.org/10.32014/2020.2518-170X.13

[6] Bitimbaev, M.Z., Krupnik, L.A., Aben, E.K., \& Aben, K.K. (2017). Adjustment of backfill composition for mineral mining under open pit bottom. Gornyi Zhurnal, (2), 57-61. https://doi.org/10.17580/gzh.2017.02.10

[7] Rzhevskiy, V.V. (2014). Otkrytye gornye raboty. Tekhnologiya kompleksnaya mekhanizatsiya. Moskva, Rossiya: Librokom, $552 \mathrm{~s}$

[8] Kutuzov, B.N. (2018). Metody vedeniya vzryvnykh rabot. Chast'1. Razrushenie gornykh porod vzryvom. Moskva, Rossiya: Gornaya kniga, $476 \mathrm{~s}$.

[9] Kutuzov, B.N. (2018). Metody vedeniya vzryvnykh rabot. Chast'. 2. Vzryvnye raboty $v$ gornom dele $i$ promyshlennosti. Moskva, Rossiya: Gornaya kniga, $512 \mathrm{~s}$.

[10] Rakishev, B.R. (1983). Prognozirovanie tekhnologicheskikh parametrov vzorvannykh porod na kar'yerakh. Alma-Ata, Kazakhstan: Nauka, $240 \mathrm{~s}$.

[11] Ushakov, D.K. (2019). Analiz faktorov, vliyayushchikh na ustoychivost' skal'nykh porod v bortakh kar'year. Vestnik ZabGU, 25(1), 29-35. https://doi.org/10.21209/2227-9245-2019-25-1-29-36

\section{Дослідження впливу буропідривних робіт на стійкість \\ бортів кар'єра Кусмурин, Республіка Казахстан}

\section{Б. Хусан, Д. Таханов, С. Кузьмін, С. Абдібаітов}

Мета. Дослідження впливу буропідривних робіт на характер деформування прибортових масивів у проектних контурах кар'єра та оцінка сейсмічного впливу вибухових робіт для розробки рекомендацій щодо раціональних параметрів буропідривних робіт.

Методика. Вплив буропідривних робіт на граничному контурі на родовищі Кусмурин вивчалося за допомогою аналізу гірничогеологічних умов і тектоніки порід, що складають родовище, натурних обстежень стану бортів кар'єра, аналізу фізико-механічних властивостей порід, що вміщують, аналітичних досліджень та інструментальних замірів дії вибуху.

Результати. Виконано розрахунок і аналіз сейсмостійкості гірських порід родовища. Шляхом інструментального виміру дії вибуху на кар'єрі отримані дані щодо сейсмічного впливу вибухових робіт на прибортовому масиві. За результатами цих робіт одержані раціональні параметри буропідривних робіт на граничному контурі кар'єра та розроблено основні положення 3 організації буропідривних робіт на граничному контурі кар'єра. Обгрунтовано технологію ведення буропідривних робіт при проведенні контурного підривання, що забезпечують довгострокове стійке положення постійного борту кар'єру.

Наукова новизна. Вперше застосовано спільний метод проведення досліджень, що включає в себе аналітичний розрахунок сейсмічного впливу ударної хвилі на масив гірських порід, за результатами якого отримані графіки залежності коефіцієнта сейсмічності від коефіцієнта твердості гірських порід родовища Кусмурин за шкалою Протод'яконова для різних вибухових речовин і метод інструментальних замірів, який слугує для визначення сейсмічного впливу вибуху на масив гірських порід.

Практична значимість. Результати роботи будуть використані для розрахунку безпечних параметрів ведення вибухових робіт при постановці борту в кінцеве положення на родовищі Космурин. Даний спосіб досліджень може бути застосований на будьякому гірничому підприємстві, що здійснює відкриту розробку корисних копалин.

Ключові слова: підривання, стійкість, борт, кар'єр, сейсмічні впливи, свердловина 
Исследование влияния буровзрывных работ на устойчивость бортов карьера Кусмурын, Республика Казахстан

\section{Б. Хусан, Д. Таханов, С. Кузьмин, С. Абдибаитов}

Цель. Исследование влияния буровзрывных работ на характер деформирования прибортовых массивов в проектных контурах карьера и оценка сейсмического воздействия взрывных работ для разработки рекомендаций по рациональным параметрам буровзрывных работ.

Методика. Влияние буровзрывных работ на предельном контуре на месторождении Кусмурын изучалось с помощью анализа горно-геологических условий и тектоники пород, слагающих месторождение, натурных обследований состояния бортов карьера, анализа физико-механических свойств вмещающих пород, аналитических исследований и инструментальных замеров действия взрыва.

Результаты. Выполнен расчет и анализ сейсмоустойчивости горных пород месторождения. Путем инструментального замера действия взрыва на карьере получены данные по сейсмическому влиянию взрывных работ на прибортовом массиве. По результатам этих работ полученны рациональные параметры буровзрывных работ на предельном контуре карьера и разработаны основные положения по организации буровзрывных работ на предельном контуре карьера. Обоснована технология ведения буровзрывных работ при проведении контурного взрывания, обеспечивающие долговременное устойчивое положение постоянного борта карьера.

Научная новизна. Впервые применен совместный метод проведения исследований, включающий в себя аналитический расчет сейсмического воздействия ударной волны на массив горных пород, по результатам которого получены графики зависимости коэффициента сейсмичности от коэффициента крепости горных пород месторождения Кусмурын по шкале Протодьяконова для различных взрывчатых веществ и метод инструментальных замеров, служащий для определения сейсмического воздействия взрыва на массив горных пород.

Практическая значимость. Результаты работы будут использованы для расчета безопасных параметров ведения взрывных работ при постановке борта в конечное положение на месторождении Космурын. Данный способ исследований может быть применен на любом горном предприятии, ведущим открытую разработку полезных ископаемых.

Ключевые слова: взрывание, устойчивость, борт, карьер, сейсмические воздействие, скважина 